\title{
Prevalence of oro-dental anomalies among schoolchildren in Sana'a city, Yemen
}

\author{
M. Basalamah ${ }^{7}$ and K. Baroudi ${ }^{7}$
}

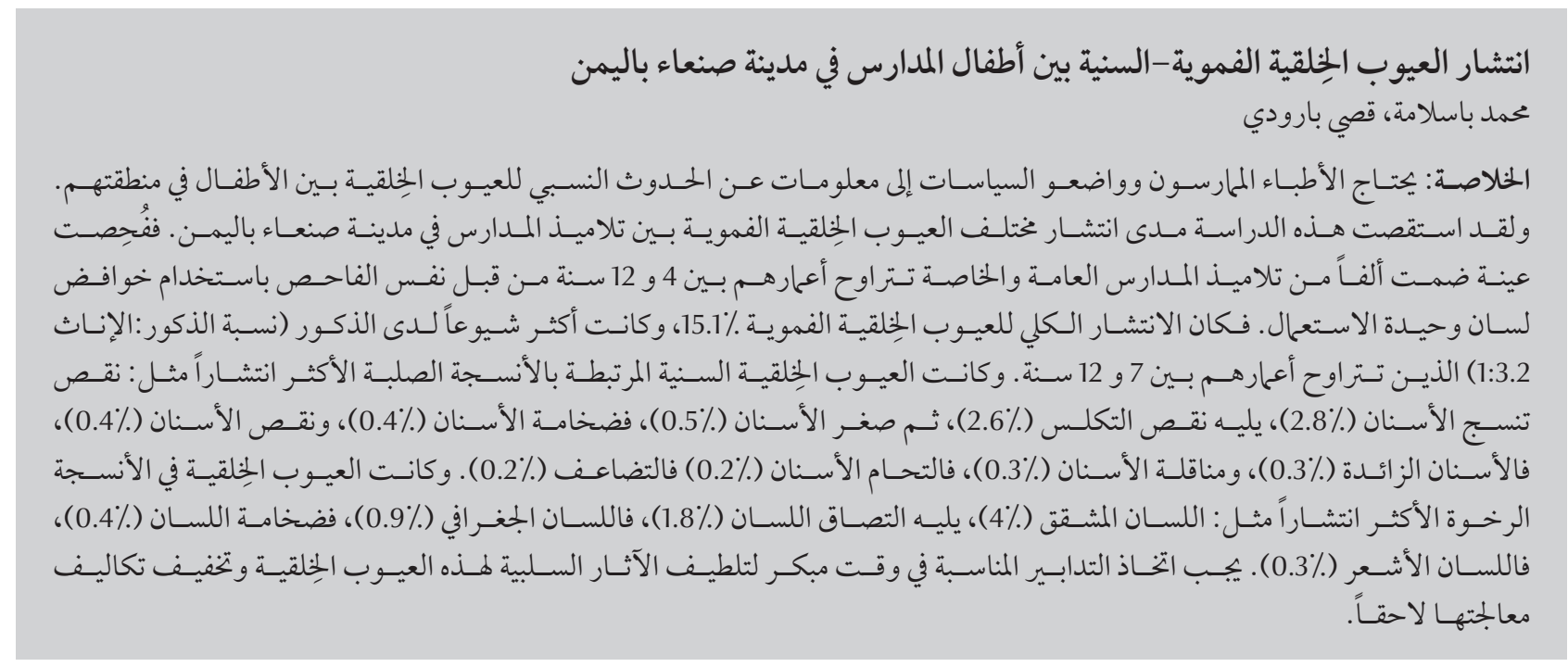

ABSTRACT Practitioners and policy-makers need information about the relative frequency of dental anomalies among children in their region. This study investigated the prevalence of different oral anomalies among schoolchildren in Sana'a city, Yemen. A sample of 1000 private and public schoolchildren aged 4-12 years were examined by the same examiner using disposable tongue blades. The total prevalence of oral anomalies was $15.1 \%$, most commonly in boys (male:female ratio 3.2:1) aged 7-12 years. The most prevalent dental anomaly related to hard tissues was tooth hypoplasia (2.8\%), followed by hypocalcification (2.6\%), then microdontia $(0.5 \%)$, macrodontia $(0.4 \%)$, hypodontia $(0.4 \%)$, supernumerary teeth $(0.3 \%)$, tooth transposition $(0.3 \%)$, dental fusion $(0.2 \%)$ and gemination ( $0.2 \%)$. The most prevalent soft tissues anomaly was fissured tongue $(4.0 \%)$, followed by ankyloglossia (1.8\%), geographic tongue $(0.9 \%)$, macroglossia $(0.4 \%)$ and hairy tongue $(0.3 \%)$. Appropriate measures need to be taken early to mitigate the negative impact and later costs of treatment of anomalies.

\section{Prévalence des anomalies bucco-dentaires chez des écoliers de la ville de Sanaa (Yémen)}

RÉSUMÉ Les praticiens et les décideurs politiques ont besoin d'informations sur la fréquence relative des anomalies dentaires chez les enfants de leur région. La présente étude a évalué la prévalence de différentes anomalies bucco-dentaires chez des écoliers de la ville de Sanaa (Yémen). Dans un échantillon, 1000 enfants âgés de quatre à douze ans fréquentant des écoles publiques et privées ont été examinés par le même praticien à l'aide d'abaisse-langue à usage unique. La prévalence totale des anomalies bucco-dentaires était de 15,1\%, le plus souvent chez les garçons (rapport garçon : fille 3,2:1) âgés de sept à douze ans. L'anomalie dentaire la plus répandue liée aux tissus durs était l'hypoplasie dentaire $(2,8 \%)$, suivie de l'hypocalcification (2,6\%), puis de la microdontie $(0,5 \%)$, la macrodontie $(0,4 \%)$, I'hypodontie $(0,4 \%)$, les dents surnuméraires $(0,3 \%)$, la transposition dentaire $(0,3 \%)$, la fusion dentaire $(0,2 \%)$ et la gémination dentaire $(0,2 \%)$. Les anomalies des tissus mous les plus prévalentes étaient une langue fissurée $(4,0 \%)$, suivies d'une ankyloglossie (1,8\%), d'une langue géographique $(0,9 \%)$, d'une macroglossie $(0,4 \%)$ et d'une langue pileuse $(0,3 \%)$. Il est nécessaire de prendre des mesures précoces appropriées pour limiter l'impact négatif puis le coût ultérieur du traitement de ces anomalies. 


\section{Introduction}

Dental anomalies are abnormalities of form, function or position of the teeth, bones and tissues of the jaw and mouth. They may affect both primary and permanent dentition, jaw articulation and the emotional development of a child (1). Dental anomalies not only cause aesthetic problems but also can lead to dental problems such as functional disorders, dental caries, pulp disease, malocclusions and in particular masticatory problems for infants and children. If untreated, these may persist throughout life leading to physical growth disorder (1).

There are more than 500 anomalies caused by simple genetic factors and perhaps an equal number of others derived from multifactorial causes or chromosome aberrations where there are orofacial alterations (2). Dental anomalies can be evidence of systemic disease and may have more than one cause (3). After evaluating the patient's symptoms, pain, health risks, family history, aesthetic considerations, treatment costs, and insurance coverage, the dentist needs to decide whether to treat or simply monitor the condition. Treatment is intended to eliminate or diminish the defect, manage pain, and alleviate the patient's concerns. In most cases, surgery can correct the deformity, and psychological services are often included as part of the treatment along with speech and hearing services (1). Although many orofacial anomalies are currently managed, rather than treated, the rapid advances of science, such as the ability to identify mutated genes, promise future cures and treatment modalities that will eliminate or reduce the number of defects currently seen (4).

Many epidemiological surveys have been conducted in different parts of the world to determine the prevalence of various types of dental anomalies. For example, Cho et al. and Ezoddini et al. found a high prevalence of supernumerary premolars and dilacerations in Chinese and Iranian children $(5,6)$. These earlier results have shown that there are regional and ethno-racial variations in the prevalence of dental and soft tissue anomalies. It is therefore important for practitioners to know the relative frequency of anomalies among children in their region in order to counsel patients who seek treatment (1). Furthermore, since dental anomalies such as missing teeth, supernumerary teeth and gemination problems are important etiological factors of malocclusion, it is essential to detect these anomalies in the primary and mixed dentition stages, as they can give rise later to serious complications including malocclusion. The aims of study therefore were to investigate the prevalence of different oral anomalies among schoolchildren in Sana'a city, Yemen, and to determine the age and sex distribution of these anomalies.

\section{Methods}

\section{Study design and setting}

This cross-sectional study was carried out in 2010 in different areas of Sana'a city. Before conducting the survey, information about the study was sent and written approval was obtained for the conduct of the study from the dean of medical science at the University of Science and Technology, Sana'a, the general manager of education and culture of each district in Sana' a city and the managers of schools in each district in Sana'a city. The parents of schoolchildren were also given information and asked to give permission for their children to participate in the research.

\section{Sampling}

This study was conducted on 1000 students (500 boys and 500 girls) out of the total school enrolment in Sana'a city of 122500 . As socioeconomic level was a factor in this study, it was conducted on children from both private and public schools, selected randomly from 6 different areas of Sana'a city according to a recent geographical map of the city. Using cluster sampling techniques 500 children (aged 4-6 years) were selected from 4 private preschools and 500 children (aged 7-8 years) from 5 public primary schools, out of 833 schools from the 6 districts of education in the city. Students who were aged 4-12 years and showed good cooperation during examination were recruited for the study.

\section{Data collection}

Before the examinations started, the examiner gave information to the students about the teeth and oral cavity and normal structure. Mouth examinations were carried out throughout the study by a single examiner (the principal investigator) wearing gloves and gauze mask. Each child was examined under natural light with a disposable plane mouth mirror, with a tongue blade to retract the cheek. The sole objective was to detect dental anomalies related to soft and hard tissues.

A data collection chart was designed for recording the necessary information for each child, including personal data such as name, age, sex and birth date.

The diagnosis of oral anomalies was made according to the clinical criteria described by Shafer et al. in 2000 (7).

\section{Statistical analysis}

Data analysis was carried out using the chi-squared test. Statistical analyses were considered significant at $P<0.05$.

\section{Results}

We found dental anomalies in 151 of the 1000 children examined, giving an overall prevalence of oral anomalies of $15.1 \%$ (23.0\% in boys and $7.2 \%$ in girls) (Table 1). The prevalence of oral anomalies was significantly higher among boys ( $115 / 500$ cases $23.0 \%)$ than girls (36/500 cases; $7.2 \%)$ (male to female ratio 3.2:1) $(P<0.05)$. 


\section{Hard tissue anomalies}

The most prevalent anomaly related to dental hard tissues was tooth hypoplasia in ( 28 cases; $2.8 \%$ ), followed by hypocalcification (26 cases; $2.6 \%$ ), then microdontia ( 5 cases; $0.5 \%$ ), macrodontia ( 4 cases; $0.4 \%$ ), hypodontia ( 4 cases; $0.4 \%$ ), supernumerary teeth ( 3 cases; $0.3 \%$ ), tooth transposition (3 cases; $0.3 \%$ ), dental fusion ( 2 cases; $0.2 \%$ ) and gemination ( 2 cases; $0.2 \%$ ). (Figure 1).

The cases of dental fusion and tooth gemination were found only in boys (Figure 1). Microdontia was detected in 3 boys and 2 girls; this anomaly affected only the anterior region. More boys than girls had macrodontia ( 3 boys and 1 girl). Dental hypoplasia, occurring mostly in the upper jaw, affected 20 teeth in boys and 8 teeth in girls. Tooth hypocalcification was observed in 22 boys and 4 girls; all cases were seen in the upper jaw only. Dental transposition occurred in 1 boy and 2 girls. Tooth transposition usually involved the maxillary canine-lateral incisor. Hypodontia was seen in 2 boys and 2 girls; the maxillary lateral incisors were the most frequently absent teeth in both sexes. There were no congenitally missing primary teeth. Oligodontia (congenital absence of 6 or more teeth) was seen in only 1 case. Supernumerary primary teeth were also found only in boys and occurred mostly in the anterior region as mesiodens.

\section{Soft tissue anomalies}

Fissured tongue was the most prevalent anomaly of oral soft tissues (40 cases; $4.0 \%$ ), followed by ankyloglossia (18 cases; $1.8 \%$ ), geographic tongue (9 cases; $0.9 \%$ ), macroglossia (4 cases; $0.4 \%$ ) and hairy tongue ( 3 cases; $0.3 \%$ ) (Figure 2).

More of the cases of ankyloglossia were found in boys ( 13 cases) than girls (5 cases) (Figure 2). The same was true for geographic tongue ( 7 boys and 2 girls) and fissured tongue (30 boys and 10 girls). Hairy tongue and macroglossia occurred only in boys.

\section{Discussion}

Study of the most common dental anomalies is important for accurate and effective treatment planning. These anomalies cause a variety of clinical problems and therefore early diagnosis should be made to avoid future problems and to plan comprehensive management.

There was a gender difference in the prevalence of all anomalies in the present study, with a higher prevalence in boys: $23.0 \%$ of boys and $7.2 \%$ of girls. The reason for this difference might be related to ethnic and racial factors. Dental anomalies are caused by inherited genetic defects. Environmental and pathological factors may also be the cause (8). In relation to Yemen's children several environmental factors such as chronic dry mouth, vitamin deficiency and oral use of certain drugs may be responsible for some of the anomalies (9). Our finding was in agreement with Aljawfi's report of tongue anomalies among Yemeni children in 2013 (9). It also agrees with a study

\begin{tabular}{|c|c|c|c|c|c|c|}
\hline \multirow[t]{2}{*}{ Anomaly } & \multicolumn{2}{|c|}{ Boys $(n=500)$} & \multicolumn{2}{|c|}{ Girls $(n=500)$} & \multicolumn{2}{|c|}{ Total $(n=1000)$} \\
\hline & No. & $\%$ & No. & $\%$ & No. & $\%$ \\
\hline \multicolumn{7}{|l|}{ Hard tissue anomalies } \\
\hline Enamel hypoplasia & 20 & 4.0 & 8 & 1.6 & 28 & 2.8 \\
\hline Hypocalcification & 22 & 4.4 & 4 & 0.8 & 26 & 2.6 \\
\hline Microdontia & 3 & 0.6 & 2 & 0.4 & 5 & 0.5 \\
\hline Macrodontia & 3 & 0.6 & 1 & 0.2 & 4 & 0.4 \\
\hline Hypodontia & 2 & 0.4 & 2 & 0.4 & 4 & 0.4 \\
\hline Supernumerary teeth & 3 & 0.6 & 0 & 0.0 & 3 & 0.3 \\
\hline Dental transposition & 1 & 0.2 & 2 & 0.4 & 3 & 0.3 \\
\hline Dental fusion & 2 & 0.4 & 0 & 0.0 & 2 & 0.2 \\
\hline Gemination & 2 & 0.4 & 0 & 0.0 & 2 & 0.2 \\
\hline \multicolumn{7}{|l|}{ Soft tissue anomalies } \\
\hline Fissure tongue & 30 & 6.0 & 10 & 2.0 & 40 & 4.0 \\
\hline Ankyloglossia & 13 & 2.6 & 5 & 1.0 & 18 & 1.8 \\
\hline Geographic tongue & 7 & 1.4 & 2 & 0.4 & 9 & 0.9 \\
\hline Macroglossia & 4 & 0.8 & 0 & 0.0 & 4 & 0.4 \\
\hline Hairy tongue & 3 & 0.6 & 0 & 0.0 & 3 & 0.3 \\
\hline Total & 115 & 23.0 & 36 & 7.2 & 151 & 15.1 \\
\hline
\end{tabular}




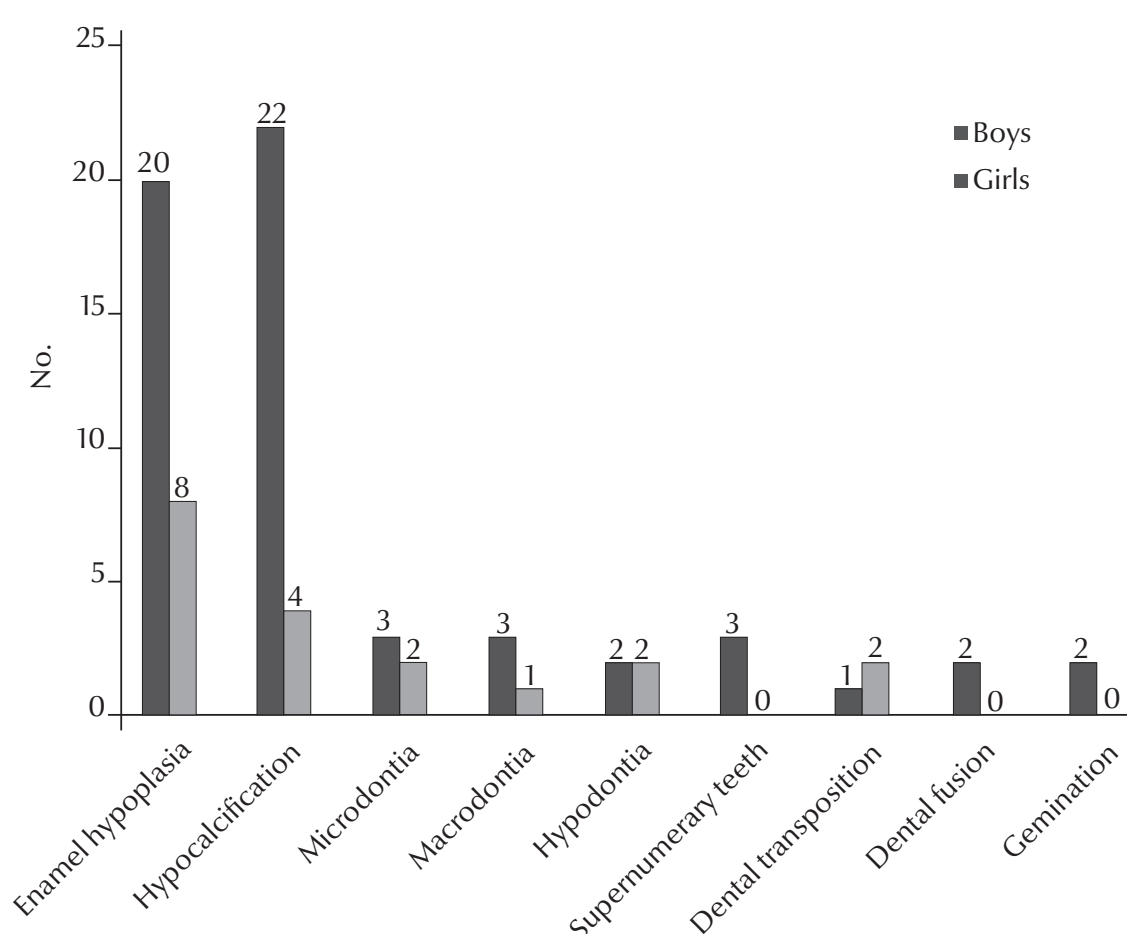

Figure 1 Prevalence (number of cases) of hard tissue anomalies among the sample of boys $(n=500)$ and girls $(n=500)$ in Sana'a, Yemen

of dental anomalies in neighbouring Saudi Arabia (1) and elsewhere in the world, from New Zealand (10). The results disagree, however, with a study in Australia, which reported that dental anomalies occurred more frequently in girls than boys. This lack of agreement can be attributed to their small sample size and the much higher ratio of girls to boys (65:46) in their study sample (11).

The prevalence of dental fusion of this study was $0.2 \%$. This is in agreement with findings from the New Zealand study $(0.4 \%)(10)$ but is much lower than in studies from Saudi Arabia or in Brazil, which found the prevalence of dental fusion to be $1.3 \%$ and $3.7 \%$ respectively $(1,12)$. This might be attributed to the large numbers of examiners (5 trained examiners) in those studies as against the use of a sole examiner in our study. Dental fusion in the present study was found in boys only, whereas the study in New Zealand found fusion in 4 boys and 2 girls (10). This can be attributed to genetic predisposition and racial differences, which have also more so in the anterior region as mesiodens than in other parts of the arches (13). This can be related to hypergenesis of the epithelial cord and hereditary and developmental defects such as cleft lip and palate. It may also be an autosomal dominant trait, with splitting of the permanent tooth germ.

The present results found hypodontia in $0.4 \%$ of the study sample, which is similar to results from Brazil $(0.6 \%)$ (12), but is considerably lower than findings from Sweden (7.4\%) (13). The difference may be due to the size of the Swedish study sample. Hypodontia can be caused by mechanical trauma to the jaw during tooth formation, or due to infection (16).

The prevalence of tooth transposition in the present study $(0.3 \%)$ fell within the range reported in a study carried out in India (0.4\%) (17). The present study showed a higher incidence of tooth transposition among girls, in agreement with an earlier report from Israel (18). One study reported that transpositions were more commonly observed in males (17) while the study in Israel reported the opposite (18). We found that transpositions were more common in the maxilla than in the mandible. We also found that most transpositions occurred in the maxillary canine-lateral incisor. This can be related to hereditary or genetic factors or to migration during tooth formation. Trauma to deciduous teeth has also been suggested as a causative factor.

The prevalence of microdontia in the present study was $0.5 \%$, which falls within the prevalence range reported by studies in Brazil (0.3\%) (12) and Japan (0.7\%) (19). Microdontia were seen only in the anterior region of both maxillary and mandibular arches, as found in the Brazilian study (12). This may be due to hereditary factors. Similarly, the prevalence of macrodontia in our study was $0.4 \%$. This is in agreement with the finding of $0.2 \%$ from Sweden (13). Macrodontia of a single tooth is rare (20). 


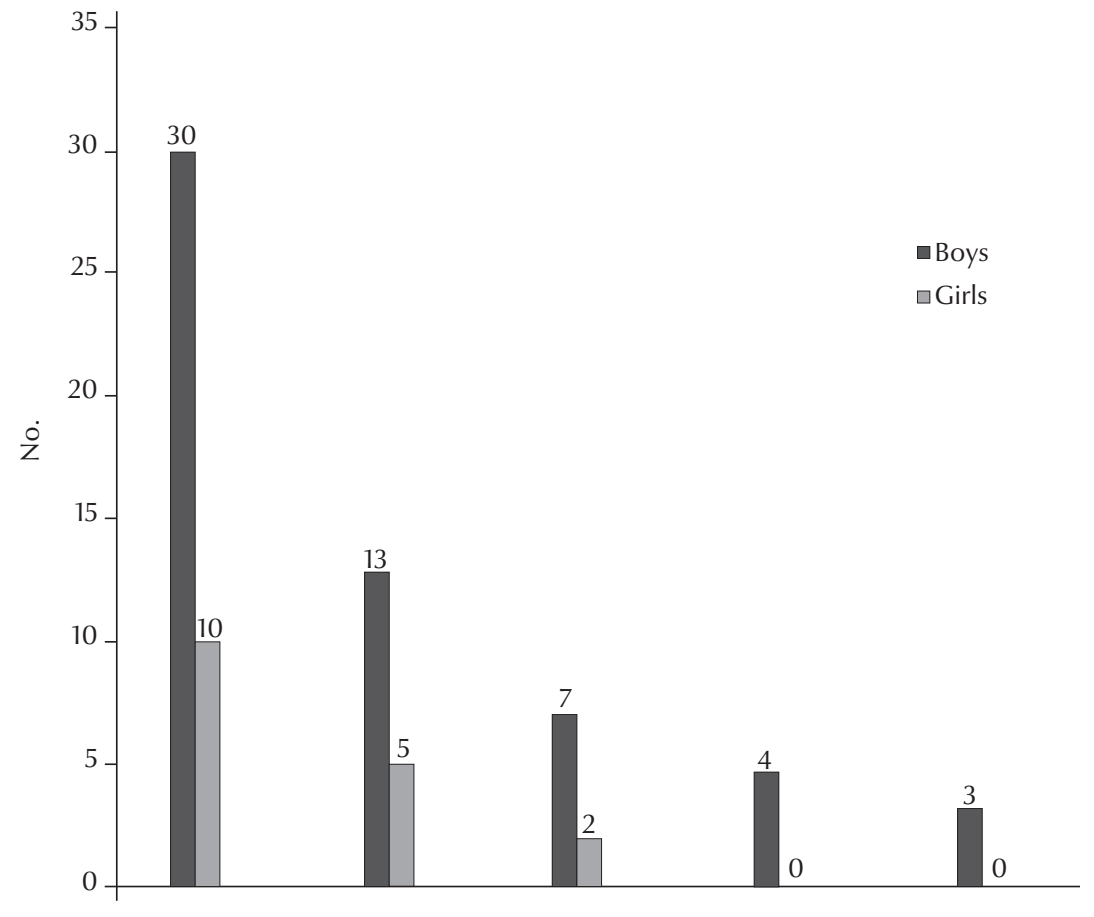

Fissure tongue Ankyloglossia Geographic tongue Macroglossia Hairy tongue

Figure 2 Prevalence (number of cases) of soft tissue anomalies among the sample of boys $(n=500)$ and girls $(n=500)$ in Sana'a, Yemen

Enamel hypoplasia was the most prevalent dental anomaly in this study at $2.8 \%$, which is higher than the figure of $1.5 \%$ reported in Japanese children (2), but lower than $3.5 \%$ found among Brazilians (21). Enamel hypoplasia can be attributed to local infections or systemic disturbances during childhood illnesses. Of our 28 cases, there were 2 children with enamel hypoplasia in the lower arch. The other cases had hypoplasia that affected the upper anterior teeth. These findings were in agreement with those of authors in South Africa (22) and Islamic Republic of Iran (23), who found hypoplasia more commonly in the upper arch than in the lower. This can be attributed to mechanical trauma or hereditary factors, as suggested in a study of Mexican children (24).
The prevalence of hypocalcification in our study population was $2.6 \%$, much lower than $23.96 \%$ found among Iranian children (23) and the range of $10-19 \%$ mentioned by Kellerhoff and Lussi in their review article (25).

The prevalence of ankyloglossia in this study was $1.8 \%$. This figure is relatively low compared with reports from other populations in the world. For example, in a study of 1540 Iranian 7-17-year-old children the prevalence of ankyloglossia was 5\% (3).

The present survey showed that $0.9 \%$ of children had geographic tongue. The reported frequency of geographic tongue in children varies widely in the literature. Our finding is lower than the figures of $2.5 \%$ among institutionalized orphans in Yemen (26) and 6.8\% in Jordanian dental outpatients (27).
However, a study of 2-17-year-old American children reported a similar figure of $1.05 \%$ (28).

The prevalence of fissured tongue in this study was $4.0 \%$. The rate differs from the reports from Jordan (11.4\%) (27) and the Islamic Republic of Iran (11.8\%) (3). The difference may be due to congenital anomalies or environmental factors such as chronic dry mouth or chronic trauma and vitamin deficiency.

Hairy tongue was observed in $0.3 \%$ of our subjects, compared with $0.8 \%$ reported by Aljawfi in Sana'a, Yemen in 2013 (9) and 0.8\% among Iranian children (3). However, it is less than the rate of $3.4 \%$ among Jordanian children (27). The difference in prevalence can be attributed to several predisposing factors such as oral use of certain drugs, chronic dry mouth or chronic trauma and vitamin deficiency.

The present survey showed that $0.4 \%$ of boys had macroglossia, compared with none of the girls, perhaps due to overdevelopment of the musculature.

There were some limitations to the study. We only sampled children in schools, so children who were not attending school (probably the poorest children) were not included. Also, we only sampled children in Sana'a so the results cannot be generalized to all Yemeni children. Large-scale population-based studies would be required to further refine our understanding of the genetics and hereditary of these anomalies. Nevertheless, the study has provided baseline data on the prevalence of oro-dental anomalies in schoolchildren in Sana'a. It is vital that assessment be carried out periodically to identify these anomalies early in life so that appropriate measures are taken early to mitigate their negative impact and costs of treatment in adult life. 


\section{References}

1. Osuji O, Hardie J. Dental anomalies in a population of Saudi Arabian children in Tabuk. Saudi Dent J. 2002;14(1):11-4.

2. Miziara R, Mendes-Junior C, Wiezel C, Simoes A, Scuoteguazza J. Azoubel, R. A Statistical Study of the Association of Seven Dental Anomalies in the Brazilian Population. International Journal of Morphology. 2008;26(2):403-6.

3. Khozeimeh F, Rasti G. The prevalence of tongue abnormalities among the school children in Borazjan, Iran. Dent Res J. 2006;3(1):1-2.

4. Tai C-CE, Sutherland IS, McFadden L. Prospective analysis of secondary alveolar bone grafting using computed tomography. J Oral Maxillofac Surg. 2000 Nov;58(11):1241-9. PMID:11078135

5. Cho SY, Ki Y, Chu V, Chan J. Concomitant developmental dental anomalies in Chinese children with dens evaginatus. Int J Paediatr Dent. 2006 Jul;16(4):247-51. PMID:16759321

6. Ezoddini AF, Sheikhha MH, Ahmadi H. Prevalence of dental developmental anomalies: a radiographic study. Community Dent Health. 2007 Sep;24(3):140-4. PMID:17958073

7. Shafer H. Levy. Text book of oral pathology. 4th ed. Philadelphia: Harcourt Asia PTE Saunders; 2000. pp. 38-47.

8. Ghaznawi H, Daas H, Salako N. A clinical and radiographic survey of selected dental anomalies and conditions in Saudi Arabian population. Saudi Dent J. 1999;11(1):8-13.

9. Aljawfi K. Frequency of tongue anomalies among Yemeni children in dental clinics. Yemeni J Med Sci. 2013; (7):1-33.

10. Whittington BR, Durward CS. Survey of anomalies in primary teeth and their correlation with the permanent dentition. N Z Dent J. 1996 Mar;92(407):4-8. PMID:8649664

11. Thongudomporn U, Freer TJ. Prevalence of dental anomalies in orthodontic patients. Aust Dent J. 1998 Dec;43(6):395-8. PMID:9973708

12. Kramer PF, Feldens CA, Ferreira SH, Spiguel MH, Feldens EG. Dental anomalies and associated factors in 2- to 5-year-old Brazilian children. Int J Paediatr Dent. 2008 Nov;18(6):434-40. PMID:18435724

13. Bäckman B, Wahlin YB. Variations in number and morphology of permanent teeth in 7-year-old Swedish children. Int J Paediatr Dent. 2001 Jan;11(1):11-7. PMID:11309867

14. Balkees T. Garib. The prevalence of oral developmental disturbances and dental alignment anomalies in females of secondary schools in Thamar city (14-21 years). J Bagh College Dentistry. 2006;18(2):35-9.

15. Brook AH. A unifying aetiological explanation for anomalies of human tooth number and size. Arch Oral Biol. 1984;29(5):3738. PMID:6611147
16. Rasmussen P. Severe hypodontia: diversities in manifestations J Clin Pediatr Dent. 1999 Spring;23(3):179-88. PMID:10686864

17. Chattopadhyay A, Srinivas K. Transposition of teeth and genetic etiology. Angle Orthod. 1996;66(2):147-52. PMID:8712493

18. Shapira Y, Kuftinec MM. Maxillary tooth transpositions: characteristic features and accompanying dental anomalies. Am J Orthod Dentofacial Orthop. 2001 Feb;119(2):127-34. PMID:11174558

19. Fujita Y, Hidaka A, Nishida I, Morikawa K, Hashiguchi D, Maki $\mathrm{K}$. Developmental anomalies of permanent lateral incisors in young patients. J Clin Pediatr Dent. 2009 Spring;33(3):211-5. PMID:19476093

20. Dugmore CR. Bilateral macrodontia of mandibular second premolars: a case report. Int J Paediatr Dent. 2001 Jan;11(1):6973. PMID:11309876

21. Yonezu T, Hayashi Y, Sasaki J, Machida Y. Prevalence of congenital dental anomalies of the deciduous dentition in Japanese children. Bull Tokyo Dent Coll. 1997 Feb;38(1):27-32. PMID:9566151

22. Hargreaves JA, Cleaton-Jones PE, Roberts GJ, Williams SD. Hypocalcification and hypoplasia in primary teeth of pre-school children from different ethnic groups in South Africa. Adv Dent Res. 1989 Sep;3(2):110-3. PMID:2640421

23. Asl Aminabadi N, Ghertasi Oskouei S, Pouralibaba F, Jamali Z, Pakdel F. Enamel defects of human primary dentition as virtual memory of early developmental events. J Dent Res Dent Clin Dent Prospects. 2009 Fall;3(4):110-6. PMID:23230497

24. Goodman AH, Allen LH, Hernandez GP, Amador A, Arriola LV, Chávez A, et al. Prevalence and age at development of enamel hypoplasias in Mexican children. Am J Phys Anthropol. 1987 Jan;72(1):7-19. PMID:3826330

25. Kellerhoff NM, Lussi A. ["Molar-incisor hypomineralization"]. Schweiz Monatsschr Zahnmed. 2004;114(3):243-53. PMID:15106501

26. Al-Maweri SA, Al-Soneidar WA, Halboub ES. Oral lesions and dental status among institutionalized orphans in Yemen: a matched case-control study. Contemp Clin Dent. 2014 Jan;5(1):81-4. PMID:24808701

27. Darwazeh AM, Pillai K. Prevalence of tongue lesions in 1013 Jordanian dental outpatients. Community Dent Oral Epidemiol. 1993 Oct;21(5):323-4. PMID:8222611

28. Shulman JD. Prevalence of oral mucosal lesions in children and youths in the USA. Int J Paediatr Dent. 2005 Mar;15(2):8997. PMID:15790365 